\title{
ADNEXAL MASSES IN PREGNANCY: BASKENT UNIVERSITY EXPERIENCE
}

Polat DURSUN, Filiz F. YANIK, Esra CABUK, Hulusi B. ZEYNELOGLU, Berk BILDACI, Esra KUSCU, Ali AYHAN

Department of Gynecology and Obstetric, Faculty of Medicine, Ege University, Izmir, Turkey

\begin{abstract}
SUMMARY
Background: Adnexal mass in pregnancy is a rare situation in daily clinical practice. Also, there is no consensus about the management of the adnexal mass diagnosed during pregnancy.

Material methods: In this study, we retrospectively identified adnexal mass which was diagnosed during antenatal follow-up or cesarean section between 2000-2009 in Başkent University Hospital,Department of obstetricsgynecology.Labor-delivery unit database, hospital records and pathology reports were evaluated in order to retrive the age of patients, number of gravida and parity, initial symptoms, the gestational age and the diameter of cyst, antenatal complications, time of delivery birth weight, indication of cesarean delivery, the type of surgical intervention during cearean delivery and pathology of the cyst.

Results: We identified 27 pregnancy complicated with adnexal masses among the 2150 delivery (1.25\%). Among these, 25 of 27 pregnants were asymptomatic (92,6\%) while just 2 pregnant women came with the complaint of pain. In 2 of the patients (7,4\%) the cyst was known before the pregnancy while in 6 pregnant women $(22,4 \%)$ the cyst was diagnosed during antenatal care. Also, rest of the women $(n=19,70,4 \%)$ were diagnosed during cesarean. The 3 of the cysts (11,1\%) was smaller than $6 \mathrm{~cm}$ while another 3 of the cysts $(11,1 \%)$ was greater than $6 \mathrm{~cm}$. Cesarean and cystectomy was performed in 23 of this women. On the other hand, 2 of them had cesarean and unilateral ooferectomy.Pathologic examinations reported as; 6(22,2\%) dermoid cyst, 3 (11,1\%) endometrioma, 4(14,8\%) seros cystadenoma, 3(\%11.1) Morgagni cyst, 4(\%14.8) mucinous cyst, 3(\%11.1) follicular cyst, 2(\%7.4) siderophagic cyst, 1(\%3.7) fibrom, 1 (\%3.7) thecoma.
\end{abstract}

Conclusion: Most of the adnexal masses diagnosed during antenatal period or cesarean section is benign. Therefore, if there is no sign of malignancy it can be conservatively managed during pregnancy and cesarean section.

Key words: adnexal mass, dermoid cyst, ovarian cyst, pregnancy

Journal of Turkish Society of Obstetrics and Gynecology, (J Turk Soc Obstet Gynecol), 2011; Vol: 8 Issue: 2 Pages: $113-7$

\section{ÖZET}

\section{GEBELİKTE GÖRÜLEN ADNEKSIYYL KISTLER: BAŞKENT ÜNIVERSITESİ DENEYIMİ}

Amaç: Antenatal takipleri sırasında ve/veya sezaryen sirasında saptanan adneksiyal kitlelerin takip ve tedavi sonuçlarının literatür bulgularıla karşılaşıtırlmalı olarak değerlendirilmesidir.

Gereç ve yöntemler: Başkent Üniversitesi Tıp Fakültesi Kadın Hastalıklarl ve Doğum Kliniği'nde 2000-2009 yılları arasında doğum yapan hastaların hastane kayıtları retrospektif olarak incelenip, bu hastaların yaşları, başvuru

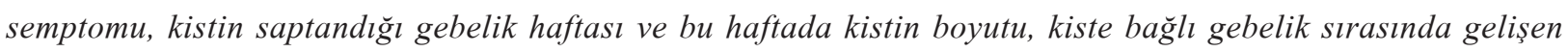
komplikasyonlar, kiste yapılan cerrahi girişimler, kistin histopatolojik değerlendirmesi sonuçları kullanılmıştır. Bulgular: Takip edilen 2150 gebenin 27 tanesinde over kisti saptanmıştır (\%1.25) Yirmibeş (\%92.6) hastanın adneksiyel

Address for Correspondence: Polat Dursun. Başkent Üniversitesi Tıp Fakültesi, Kadın Hastalıkları ve Doğum Anabilim Dalı, Maltepe, Ankara Phone: +90(532) 3845158

e-mail: pdursun@yahoo.com

Received: 26 May 2010, revised: 08 December 2010, accepted: 24 December 2010, online publication: 14 March 2011 
kisti asemptomatik olup, sadece 2(\%7.4) hasta ağrl şikayeti ile başvurmuştur. İki (\%7.4) hastadaki over kisti gebe kalmadan önce de bilinirken, 6(\%22.4) hastada gebelik esnasında, 19(\%70.4) hastada ise sezaryen sırasında kist saptanmıştır. Antenatal takiplerinde 3(\%11.1) hastada kistin boyutu 6 cm'den küçük, 3 (\%11.1) hastada kistin boyutu $6 \mathrm{~cm}$ 'den büyük idi. Yirmi üç hastaya sezaryen ve kistektomi, 2 hastaya sezaryen ve unilateral ooferektomi, 1 hastaya 19 haftalı gebeliği sirasında laparotomi ile unilateral salpingooferektomi ve omentektomi, 1 hastaya 17 haftalık gebeliği sırasında laparoskopi ile kist eksizyonu yapıldı. Patoloji sonuçları $6(\% 22,2)$ dermoid kist, 3(\%11.1) endometrioma, 4(\%14.8) seröz kistadenom, 3(\%11.1) Morgagni kisti, 4(\%14.8) musinöz kist, 3(\%11.1) folikül kisti, 2(\%7.4) siderofajik kist, 1(\%3.7) fibroma,1(\%3.7) tekoma ile uyumlu idi.

Sonuç: Klinik muayene ve görüntüleme yöntemleri ile benign bir kitleden şüpheleniyorsa, hastada herhangi bir bulgu vermiyorsa kist doğuma kadar izlenebilir. USG daha pratik bir yaklaşım olduğundan gebe hastalara ilk obstetrik USG muayenesinden itibaren her iki adneks rutin olarak değerlendirilmelidir. Sezaryen sirasında tespit edilen tüm kistik yapılar şüphe varsa patolojiye gönderilip malignensi olasılı̆̆ı ekarte edilmelidir.

Anahtar kelimeler: adneksiyal kitle, gebelik, ovaryen kist

Türk Jinekoloji ve Obstetrik Derneği Dergisi, (J Turk Soc Obstet Gynecol), 2011; Cilt: 8 Sayl: 2 Sayfa: 113- 7

\section{INTRODUCTION}

Frequency of adnexal masses during pregnancy vary between $1 / 81$ and 1/8000 and adnexal masses seen during pregnancy are generally benign. The most frequently seen histological types are; mature cystic teratoma at $50 \%$, functional cyst at $13 \%$, cystadenoma at $20 \%$ and ovarian cancer at $0,6 \%(1,2)$.

Adnexal masses generally progress asymptoma-tically and are resorbed spontaneously before the 16th week; after the 16 th week cysts are generally seen through complications $^{(1)}$. USG and MRG have a significant place in monitoring the cysts during pregnancy ${ }^{(2)}$. Approach to adnexal mass during pregnancy; should be done especially via surgical intervention after determining the intervention required acute state indications ${ }^{(3)}$.

Our aim in this study is to evaluate the follow-up and treatment results of the adnexal masses determined during antenatal follow-up and/or cesarean in our clinic with the findings in literature.

\section{METHOD AND MATERIALS}

In this study, delivery room and hospital records of the patients who gave birth in Başkent University Hospital, Department of obstetricsgynecology, Labordelivery unit between the years January 2000-December 2009 were examined and records of the cases in which adnexal mass was determined during antenatal follow- up or birth were reviewed retrospectively. Patient's age, gravidity and parity, presenting symptom, pregnancy week in which mass was determined and size of the mass in this week, mass related antenatal problems developing during pregnancy, pregnancy week of the birth, weight of the newborn, indication if the birth was by caesarean section, surgical intervention performed for the mass and histopathologic examination results were noted and evaluated with general statistical methods using the SPSS statistics program.

\section{RESULTS}

2150 pregnant women gave birth in Başkent University Hospital, Department of obstetrics gynecology, Labordelivery unit between the years 2000-2009. Ovary cyst was determined in a total of $27(1.25 \%)$ patients; before pregnancy in 2, during antenatal follow-ups in 6 and during caesarean in 19 .

Mean age of our pregnant patients with an adnexal mass was 30,9. $20(74.1 \%)$ of these were primigravida and $7(25,9 \%)$ were multigravida. Adnexal mass of 25 $(92.6 \%)$ patients was asymptomatic and only $2(7.4 \%)$ had a pain complaint. While ovary cyst of $2(7.4 \%)$ patients were already known before getting pregnant, cyst was determined in $6(22.4 \%)$ patients during pregnancy and in $19(70.4 \%)$ patients during caesarean. Mean week in which cyst was determined was $10 \pm 5$ in six $(22.4 \%)$ patients. In antenatal follow-ups, mass 
size was $<6 \mathrm{~cm}$ in $3(11.1 \%)$ patients and was $>6 \mathrm{~cm}$ in $3(11.1 \%)$. Regarding the masses determined during caesarean, mass size of $4(14.8 \%)$ patients was above $6 \mathrm{~cm}$ and of 15 (55.5\%) patients was below $6 \mathrm{~cm}$ (Table I). Of the patients followed by USG during antenatal follow-ups, the appearance of the mass was thickwalled and involved echogenicity in 2, cystic appearance with advanced hypoechogenicity was present in 3, cystic mass appearance with simple septa was present in 2 and mass appearance was of mixed echoic type with dense solid components was present in 1 .

Table I : Determination time of the adnexal masses in pregnancy and their sizes.

\begin{tabular}{llll}
\hline \multicolumn{4}{c}{ Size of the cyst } \\
Number of patients & Above 6>cm & Below 6 cm & Total \\
\hline During caesarean & $4(\% 14.8)$ & $15(\% 55.5)$ & $19(\% 70.3)$ \\
Antenatal & $3(\% 11.1)$ & $3(\% 11.1)$ & $6(\% 22.2)$ \\
Prepregnancy & $0(\% 0)$ & $2(\% 7.5)$ & $2(\% 7.5)$ \\
TOTAL & 7 & 20 & $27(\% 100)$ \\
\hline
\end{tabular}

Of the masses that were determined antenatally, growth of $2 \mathrm{~cm}$ was determined in only $2(7.5 \%)$ patients' masses (Table II). 25 (92.6\%) patients were followed without any complication, $1(3.7 \%)$ patient had neonatal cholestasis and 1(3.7\%) patient was followed with the diagnosis of preterm labor. Infant weight in one patient $(3.7 \%)$ whose mass was determined during caesarean was 2400 gr and the baby was followed up with the diagnosis of SGA; infant weights in 26 (96.3\%) patients were over $2500 \mathrm{gr}$ and the mother was discharged.

Table II: State of the cysts in follow-up.

\begin{tabular}{|c|c|c|c|}
\hline \multirow[b]{2}{*}{$\begin{array}{l}\text { Determination } \\
\text { time of the cyst }\end{array}$} & \multicolumn{3}{|c|}{ Increase in the size of the cyst } \\
\hline & Yes & No & Total \\
\hline Prepregnancy & 0 & 2 & 2 \\
\hline Antenatal & 2 & 4 & 6 \\
\hline Caesarean & 0 & 19 & 19 \\
\hline Total & 2 & 25 & 27 \\
\hline
\end{tabular}

Cyst excision was performed on twenty three patients by caesarean and cystectomy, on 2 patients by caesarean and unilateral oophorectomy, on 1 patient by laparotomy on the 19th week of pregnancy and salpingooophorec-tomy and omentectomy, on 1 patient by laparoscopy on the 17 th week of pregnancy. Or caesarean indications in these patients are $9(33.3 \%)$ elective, 5 (18.5\%) breech presentation, 5 (18.5\%) former caesarean, 3 (13.3\%) twin pregnancy, 3 (11.1\%) fetal distress and 2 (7.4\%) macrosomic baby. Ovary torsion was determined in two patients who attended with pain complaint and were operated due to acute abdomen during pregnancy. Pathology results were concordant with 6 (22.2\%) dermoid cyst, 3 (11.1\%) endometrioma, 4 (14.8\%) serous cystadenom, 3 (11.1\%) Morgagni cyst, 4 (14.8\%) mucinosis cyst, 3 (11.1\%) follicle cyst, 2 (7.4\%) siderophagic cyst, 1 (3.7\%) fibroma, $1(3.7 \%)$ thecomata. The last pathology of twenty seven patients was reported as $100 \%$ benign (Table III).

Table III: Histopathologic results of the cysts determined during caesarean.

\begin{tabular}{ll}
\hline Histopathologic type & $\mathbf{\%}$ \\
\hline Dermoid cyst & $\% 22,2$ \\
Serous cystadenom & $\% 14.8$ \\
Mucinosis cyst & $\% 14.8$ \\
Endometrioma & $\% 11.1$ \\
Morgagni cyst & $\% 11.1$ \\
Follicle cyst & $\% 11.1$ \\
Siderophagic cyst & $\% 7.4$ \\
Fibroma & $\% 3.7$ \\
Thecomata & $\% 3.7$ \\
\hline
\end{tabular}

\section{DISCUSSION}

Adnexal mass is determined in nearly $1 \%$ of the pregnant women and generally they are in benign form. The most frequently seen types are mature cystic teratoma, cystadenoma and functional cysts, respectively(1). Histological distribution of the masses determined during pregnancy in our study are found in concordant ratios with literature and frequency of adnexal mass in pregnancy has been calculated as $1.25 \%$. Dermoid cyst is the most frequent $(22.2 \%)$ pathology both in literature and in our study, then comes the serous cystadenom and mucinosis cysts.

Adnexal masses generally progress asymptomatically during pregnancy and most of them are resorbed spontaneously before the $16^{\text {th }}$ week; after the $16^{\text {th }}$ week cysts are generally observed with complications. The complications of the masses seen in pregnancy include torsioned or ruptured cyst, infectious manifestation as a result of these, cyst's pressure on urinary system, 
delaying of the birth action, malpresentation of the fetus depending on its size. Adnexal masses with a stable size or growing during pregnancy also raise doubts in terms of malignity and it is known that these masses have a malignancy risk of about $0.6 \%(5,6)$. In our study it has been observed that majority of the patients (92.6\%) progressed asymptomatically, just 2 $(7.4 \%)$ patients attended with a pain related to ovary cyst torsion on the $17^{\text {th }}$ and $19^{\text {th }}$ weeks. The leading $(21 \%)$ indication of our caesarean cases is breech presentation, this exemplifies the malpresentation which is one of the ovary cyst complications given in the literature.

Characteristics of monitoring the adnexal masses in pregnancy have a broad spectrum. USG and MRG have a significant place in monitoring the masses in pregnancy. USG, especially, is the first and most significant method in terms of evaluating the morphology of pelvic masses. Size of the mass lesion, its cystic or solid appearance, whether it involves tiny or thick septations should be indicated clearly. When diagnosis can't be established by USG, MRG is used and usage of MRG in pregnancy is regarded as reliable $^{(7,8)}$. In this study, content and solid or cystic formation of the mass are determined both in prepregnancy and antenatal period via help of USG. Ovarian masses were determined in 4 patients again via help of USG; initial cyst sizes of these patients were below $6 \mathrm{~cm}$, while growth in cyst size was determined during USG follow ups of just 2 patients, cyst sizes of 3 patients decreased spontaneously. Cyst sizes of the patients whose cysts were determined during caesarean were below $6 \mathrm{~cm}$ and no symptom was seen during their pregnancy follow-ups.

Surgical intervention to adnexal cysts should be planned for malignity, persistent asymptomatic ovary cysts $(>8-10 \mathrm{~cm})$ and symptomatic masses (torsion, rupture, birth canal's being obstructed) ${ }^{(9,10)}$. Approach to adnexal masses during pregnancy is determined according to patient's symptoms, pregnancy week, size and characteristics of the mass. Small ovary cysts $(<6 \mathrm{~cm})$ are generally functional and managed conservatively. If the mass is unilateral, unilocular, mobile and smaller than $6 \mathrm{~cm}$, follow-up is recommended(1-11). If the mass is bigger than $6 \mathrm{~cm}$, solid, bilateral or showing continuity in the second trimester, general approach is the performance of laparotomy ${ }^{(1-10)}$. Adnexal mass requiring surgery in the first trimester is generally the cyst torsion causing emergency surgical intervention (7\%). Elective surgery is delayed until the second trimester in order to decrease the risk of spontaneous abortus. In the pregnancies operated in the $18^{\text {th }}$ week, a fetal problem is very rare. So, $18^{\text {th }}$ week is considered to be the most appropriate week for surgery $(10,11)$. In this study, surgical intervention was performed on only $2(7.4 \%)$ patients in the $17^{\text {th }}$ and $19^{\text {th }}$ weeks as the cysts were torsioned. There was no problem in the pregnancy follow-up of the patient, caesarean was performed and she gave birth to a 3400 gr baby. For the patient who had a 19 week pregnancy, after the 38 weeks a 3400 gr baby was delivered through the normal vaginal way. Cystectomy was performed on 20 patients whose cysts were determined during caesarean and no complication developed in the postoperative period. Malignity wasn't determined in any of the patients in histopathological evaluation.

Consequently, if any benign mass is suspected through clinical inspection and monitoring methods and there is no finding in patient, cyst may be followed up till the birth. As USG is a more practical approach, both adnexa should be evaluated routinely dating from the first obstetrics USG inspection of the patients. All the cystic structures determined during caesarean section should be sent to pathology if any suspicion is present and malignancy should be ruled out.

\section{REFERENCES}

1. Whitecar MAP, Turner S, Higby MK: Adnexial masses in pregnancy: A review of 130 cases undergoing surgical management. Am J Obstet Gynecol 1999; 181(1): 19- 24.

2. Chiang G,Levine D.Imaging of adnexial masses during pregnancy. J Ultrasound Med 2004; 23: 805- 19.

3. Leiserowitz, Gary S. MD, Managing ovarian masses during pregnancy. Obstet Gynecol Surv. 2006 Jul; 61(7): 463- 70.

4. Gary Scott Leitsowitz: Surgical complications during pregnancy In Niswander KR, Evans AT(Eds) Manual Of Obstretics, 5th Ed. Boston, Little Brown and Company 1996; 239- 60.

5. Duic Z., Kukura V, Ciglar S, Podobnik M. Adnexial masses in pregnancy:a review of eight cases undergoing surgical managment. Eur J Gynaecol Oncol 2002; 23: 133- 4.

6. Michel E. Rivlin. Surgery and truma in pregnancy. In: Rivlin ME, Martin RW, Wiser WL, Manual of clinical problems in obsterics and gynecology, 5 th ed. Philedelpihia, Lippincott Williams and Wilkins, 2000; 126-30. 
7. Bromley B, Benacerraf B.Adnexial masses during pregnancy: Accuary of sonographic diagnosis and outcome. J Ultrasound Med. 1997 Jul; 16(7): 447- 52;

8. Nicholas A. Telischak et al. MRI of adnexial masses in pregnancy AJR Am J Roentgenol. 2008 Aug; 191(2): 364- 70.

9. Condous G, Okaro E, Bourne T. The conservative managment of early pregnancy complications: a review of the literature.
Ultrasound Obstet Gynecol 2003; 22: 420- 30.

10. Schemeler KM, Mayo-Smith WW, Peipert JF, Weitzen S, Manuel MD, Adnexial masses in pregnancy: Surgey compared with observation. Obstet Gynecol 2005; 105: 1098- 103

11. Platek DN, Handerson CE, Goldberg GL, The management of a persistent adnexial mass in pregnancy. Am J Obstet Gynecol 1995; 173: 1236- 40 . 